\title{
The problem of an objective prognosis of public danger of an insane person for the purposes of criminal proceedings
}

\author{
Andrey Sergeevich Burtsev ${ }^{*}$, Ivan Vladimirovich Mironyuk, Oksana Sergeevna Shumilina, \\ Sergey Nikolaevich Bezugly, Evgeny Aleksandrovich Ignatenko \\ Belgorod State National Research University, Department of Criminal Law and Procedure, \\ Belgorod, Russia
}

\begin{abstract}
The purpose of the article is to study the judicial practice and identify the problem of the lack of an objective medical and social prognosis of the public danger of a mentally ill (deranged) person in order to further apply compulsory medical measures, their replacement or cancellation. As a consequence, individuals who no longer pose such danger are unreasonably subjected for a long time to restrictions on civil, political, economic, social, and cultural human and civil rights and freedoms guaranteed by the Constitution of the Russian Federation and the universally recognized principles and rules of international law. The methodological basis of the research is both philosophical (dialectical, analytical) and generally scientific methods (analysis, synthesis, abstraction, generalization, induction). The work resulted in the conclusion that there is a similar problem in foreign forensic psychiatry and law and order, identifying similarities and differences in approaches to solving it, with regard to the national specifics of providing psychiatric care to the population, including in a compulsory manner. The novelty of the work is that given the objective and subjective difficulties that domestic forensic psychiatry experiences in creating a prognostic methodology of public danger of such patients, a proposal is made to consider, for these purposes, the time period during which the patient does not commit crime. Although the proposed criterion is not of a medical nature, it is always in the sight of doctors and lawyers (judge, prosecutor) when resolving legal situations related to compulsory medical measures. The authors of the article expect that in combination with the clinical variables of the risk of violence, this will allow to achieve an objective prognosis and avoid the unjustified use of medical (restrictive) measures.
\end{abstract}

Keywords: insanity, criminal law, forensic psychiatry, mentally ill, public danger

\section{Introduction}

\footnotetext{
*Corresponding author: burtsev@bsu.edu.ru
} 
The prerequisite for this study was the problem with which psychiatrists, as well as the courts, have been facing for a long time when deciding on extending, modifying, or terminating the application of compulsory measures of medical nature. Its essence is in the need to certify the fact of healing or improving the mental state of a person who previously committed a crime in a state of insanity, including by predicting the possibility of committing a repeat crime.

Despite the large theoretical base [1-4] on the issues of legislative regulation of the procedures for the use of compulsory measures of medical character, their shortcomings and gaps, it does not have a comprehensive character, since the authors of the studies either did not address the designated problem at all or did not pay enough attention to it, while completely ignoring the problems of forensic psychiatry that influence court decisions.

The purpose of the study is to combine the criminal law and medical (psychiatric) aspects in the field of application of compulsory measures of medical character, in order to outline, on the basis of their scientific potential, measures to improve the methodological tools defining the basis of the activities of medical institutions providing psychiatric care in situations requiring to confirm the presence (absence) of public danger in patients. Achieving this goal has practical and theoretical cognitive value.

\section{Methods}

To achieve this goal, the authors of this study used both philosophical (dialectical, analytical) and general scientific methods (analysis, synthesis, abstraction, generalization, induction).

\section{Results and discussion}

Insanity (from lat. furiosus - "eranged") is the most complex and at the same time important category when deciding whether a person is guilty of committing a crime. Typically, in investigative-prosecutorial, and judicial practice, this concept is synonymous with a medical diagnosis, which is the result of a forensic psychiatric examination.

Since an act with the features of a crime committed by the insane is not subject to criminal liability, the state protects society from the repeated commission of socially dangerous acts by such persons, applying compulsory measures of medical character to them associated with significant legal restrictions that do not allow them to independently and in their own interests choose the type and level of their behaviour.

The supreme judicial body of the country has determined that the purposes of the use of compulsory measures of medical character are to cure these persons, improve their mental state, prevent them from committing new acts.

For this, psychiatrists have an extensive range of medical methods (diagnosis, treatment, and rehabilitation) to be applied to patients in accordance with medical indications, as well as the regulatory framework.

Within this system, the procedure for the appointment, extension, modification or termination of the use of compulsory measures of medical character is only subject to the purpose of providing such assistance and does not have criminal legal significance [5]. However, this applies only to cases where the use of compulsory measures of medical character is not associated with punishment since this combination turns them into a "stage" for achieving the goals of criminal responsibility.

Despite the considerable amount of knowledge about mental illness, even experienced professionals face objective difficulties when it is necessary to determine whether the goal of using compulsory measures of medical character has been achieved and to what extent this has happened. In other words, whether or not a particular patient previously found by a court 
to be insane and released from punishment with the use of compulsory measures of medical character constitutes a public danger.

It should be noted that among clinical psychiatrists, there has long been consensus (lat. consensus - agreement, unanimity) on the definition of the public danger of a mentally ill person as a high probability of committing a repeated socially dangerous act [6].

For objective clinical and social prognosis of the socially dangerous behaviour of mentally ill patients, clinicians-psychiatrists proposed to perform "the analysis of a combination of clinical-psychopathological, socio-demographic and psychological variables of the risk of violence", contributing to the identification of factors that provoke the repetition of socially dangerous actions [7].

Domestic psychiatrists refer to the group of clinical and psychopathological variables the presence of psychopath-like syndromes with increased behavioural activity and pathology of desire, delusions of certain content, accompanied by affective tension, and a number of others.

Among the socio-demographic variables are the young age of the person who committed violence for the first time, the repeated violent manifestations in the past, the loss of the ability to adapt to the conditions of the social environment at an early age, alcohol and drug abuse, employment problems, the establishment of a disability group, housing and financial insolvency, the lack of stable social relations (family problems), neglect of the requirements of supervision, etc. [7].

As for the psychological variables, as noted by Belyakova, they often overlap with sociopsychological and socio-demographic factors, which largely levels off their significance [8].

This statement should not at the same time be regarded as a denial of the current state of affairs, but only as evidence of the complexity of the problem faced by forensic psychiatry. Makushkina et al., among the psychological variables, highlight emotional uncontrollability, heightened suggestibility and submissiveness, perversity and disinhibition of drives, intellectual incompetence [9].

The mentioned "triad" formed the basis of the national methodology for assessing the social danger of the mentally ill. Its essence is a comprehensive analysis of violence risk variables, the result of which is the total index of public danger of the patient, as a quantitative (ball) assessment of two indicators: severity and probability of the predicted act [10, 11], which represents the arithmetic mean between these two characteristics.

However, despite the simplicity of this approach, it has not been widely used among psychiatrists due to the lack of clear criteria for making informed judgments about the risk of socially dangerous actions by mentally ill people in order to determine whether it is necessary to continue, change or stop compulsory measures of medical character. That is, the proposed method could not provide the necessary degree of accuracy and objectivity of the prognosis.

Foreign psychiatry also changes, having accumulated the most extensive empirical material concerning the social danger of the insane and, above all, its factors.

A comparison of the achievements of domestic and foreign psychiatry (in this case it refers to the collective West, without dividing into specific countries) allowed us to identify both similarities and differences in prognostic approaches. According to [12] the most objective predictors of the public danger of the mentally ill are factors related to the group of mentally healthy criminals. At the same time, medical diagnosis is considered one of the weakest risk factors [12]. In this part, domestic psychiatry has the opposite opinion.

However, this study cannot be objective if, despite the prevalence of the above point of view [13], the fact that there are scientific papers that note a direct link between a certain psychiatric diagnosis and the frequency of violent crimes committed is ignored [14].

As well as domestic psychiatrists, foreign authors give special importance to sociodemographic factors $[15,16]$ of public danger of patients, emphasizing the role of non- 
compliance with treatment, alcohol and substance use [17], as well as violence in the past [18]. To a lesser extent, attention is drawn to such personality traits as pathology, aggressiveness, rigidity, excitability, vindictiveness [12].

What is important for us is that, regardless of the approach that domestic and foreign authors have taken to research on the public danger of the mentally ill, they distinguish a different number of variables to be considered in terms of the human groups observed.

However, as noted by Canadian forensic psychiatrists, Cameron and Gulaty [19], the problem of determining the public danger of the insane in terms of the possibility of recommitting a crime, is not as acute in North America (USA, Canada) and a number of European countries (Great Britain, etc.) as in the Russian Federation, since in the last fifty years there has prevailed the trend of discharge and treatment of patients in psychiatric hospitals at the place of residence.

Therefore, due to the current system of providing psychiatric care in our country, the need to respect and protect the constitutional rights and freedoms of man and citizen in its implementation, domestic psychiatry should as soon as possible develop objective criteria that allow with a high degree of probability to give a clinical and social prognosis of the socially dangerous behaviour of a mentally ill person.

The authors of this study, while mentioning the existence of such a problem and the need to resolve it, supported the efforts of clinicians-psychiatrists by analysing the difficulties of an objective and subjective nature that arise when the court resolves specific legal situations related to the application of the compulsory measure of medical character to certain categories of persons previously recognized by the court as insane [20]. They also addressed the inadmissibility of using vague formulations in medical and judicial practice, created with the help of incorrect concepts, and other aspects [21].

\section{Conclusion}

Returning to the subject of the present study, as a conclusion, it should be recommended to include the time factor among the considered variables (factors) of the risk of violence influencing the determination of the social danger of a mentally ill (insane) person. As proved by judicial practice, it is present and discussed by lawyers in every legal situation connected with the decision to continue to apply the compulsory measure of medical character to a person, to replace it, or to completely cancel it. The point of such consideration is that the longer the time period during which the patient does not re-offend, the more objective when combined with the medical criteria for risk of reoffending discussed, will be the doctors' prognosis, and the fewer the number of restraints the person will be subjected to.

\section{Reference}

1. E.V. Shpynova, Aktualnye Problemy Rossiyskogo Prava, 4(53), 65-72 (2015)

2. V.V. Panarina, Zakony Rossii: Opyt, Analiz, Praktika, 4 (2018)

3. K.A. Sergeev, A.B. Sergeev, Medical Law, 1 (2018)

4. Zh.A. Bazhukova, Advokate's Practice, 4 (2017)

5. G.A. Esakov, T.G. Ponyatovskaya, A.I. Rarog, A.I. Chuchaev, Ugolovno-pravovoe vozdeystvie [Criminal Law Impact: monograph], in A.I. Rarog (ed.) (Prospekt Publ., Moscow, 2012)

6. M.Yu. Belyakova, V.G. Bulygina, G.M. Tokareva, Psychologiya i Pravo [Psychology and Law], 1, 1-14 (2015) 
7. V.G. Bulygina, B.A. Kazakovcev, O.A. Makushkina et al., Faktory, sderzhivayushchie risk nasiliya. Subektivnye otsenki i reabilitatsionnyi potentsial: metodicheskie rekomendacii [Factors, which protect violence risk. Subjective evaluations and rehabilitation positional] (GNC SSP im. V.P. Serbskogo Minzdrava RF Publ., Moscow, 2014)

8. M.Yu. Belyakova, Russian Journal of Psychiatry, 4 (2015). http://dx.doi.org/10.24411/1560-957X-2015-1\%25x

9. O.A. Makushkina, V.B. Holland, L.A. Yakhimovich, Rossiyskii Psikhiatricheskii Zhurnal, 5, 5-6 (2011)

10. O.A. Makushkina, L.A. Mugantseva, Psikhicheskoye Zdorovye, 10(125), 18-26 (2016)

11. M.M. Maltseva, V.P. Kotov, M.M. Maltseva, V.P. Kotov, Opasnye deistviya psikhicheski bolnykh [Dangerous actions of the mentally ill persons] (Meditsina Publ., Moscow, 1995)

12. J. Monahan, H.J., Steadman (eds.), Violence and Mental Disorder: Developments in Risk Assessment (University of Chicago Press, Chicago, IL, 1994)

13. J. Bonta, K. Hanson, M. Law, Psychological Bulletin, 123(2), 123-142 (1998). https://doi.org/10.1037/0033-2909.123.2.123

14. R. Binder, D. McNiel, Am J Psychiatry 145(6), 728-732 (1988). https://doi.org/10.1176/ajp.145.6.728

15. J.S. Brekke, C. Prindle, S.W. Bae, J.D. Long, Psychiatric Services, 52, 1358-1366 (2001). https://doi.org/10.1176/appi.ps.52.10.1358

16. J.P. Singh, S.L. Desmarais, C. Hurducas et al., International Journal of Forensic Mental Health, 13(3), 193-206 (2014). https://doi.org/10.1080/14999013.2014.922141

17. C. Wallace, P.E. Mullen, P. Burgess, Am J Psychiatry 161, 716-727 (2004). https://doi.org/10.1176/appi.ajp.161.4.716

18. J.W. Swanson, M.S. Swartz, R. Van Dorn, E.B. Elbogen, H.R. Wagner, R.A. Rosenheck et al., Arch Gen Psychiatry 63(5), 490-499 (2006). https://doi.org/10.1001/archpsyc.63.5.490

19. K. Cameron, S. Gulaty, Russian Journal of Psychiatry, 5, 24-30 (2017)

20. A.S. Burtsev, I.V. Mironyuk, O.S. Shumilina, Nauka i Obrazovanie: Khozyaistvo i Ekonomika; Predprinimatelstvo; Pravo i Upravlenie, 11, 111-115 (2020)

21. Andrey S. Burtsev, Yaroslav I. Ivanenko, Elena A. Kupryashina, Ivan V. Mironuk, and Victor N. Omelin, International Journal of Criminology and Sociology, 9, 1033-1037 (2020). https://doi.org/10.6000/1929-4409.2020.09.115 